\title{
Corporate Governance - Performance Relationship in Microfinance Institutions (MFIs)
}

\author{
Sujani Thrikawala (Corresponding author) \\ Department of Finance, Waikato Management School, University of Waikato \\ Private Bag 3105, Hamilton 3240, New Zealand \\ Tel: 64-7-838-8182Ｅ-mail: sst7@waikato.ac.nz
}

Stuart Locke

Department of Finance, Waikato Management School, University of Waikato

Private Bag 3105, Hamilton 3240, New Zealand

E-mail: smlocke@waikato.ac.nz

\begin{abstract}
Krishna Reddy
Department of Finance, Waikato Management School, University of Waikato

Private Bag 3105, Hamilton 3240, New Zealand

E-mail: krishna@waikato.ac.nz
\end{abstract}

Received: Jan. 23, 2013

Accepted: March 29, 2013

Published: June 1, 2013

doi:10.5296/ajfa.v5i1.3119

URL: http://dx.doi.org/10.5296/ajfa.v5i1.3119

\begin{abstract}
The relationship between governance and the performance of microfinance institutions (MFIs) is discussed in this paper. MFI performance encompasses both financial performance and outreach. Good governance in terms of strengthening stewardship, achievement of MFIs' primary objectives and promoting further development of the industry have been asserted as key elements in the literature pertaining to MFI performance. Similarly, several cases concerning poor governance have been analysed.

Good corporate governance has become more important due to the demand for transparency and accountability of funds utilised in microfinance activities. Further, MFIs need to have a
\end{abstract}


solid governance framework to minimise the possibilities of management failures which may jeopardise the efficacious application of received funds from governments and donors.

In prior studies, the nature of corporate governance practised by MFIs is less understood and no substantive work using multiple MFI outcomes over a number of years has been undertaken. The concerns raised in reviews of individual MFIs and normative discussions of what should constitute best practice do point to the need for better understanding of the nature of corporate governance practised by the MFIs and also, to understand the nature of the relationship that exists between institutional success and corporate governance especially for developing countries. This study therefore identifies and provides a framework for undertaking corporate governance research relating to MFIs.

Keywords: Microfinance Institutions (MFIs), Corporate Governance Practices, Financial Performance, Outreach. 


\section{Introduction}

Economists and finance practitioners emphasize that the development of the financial service sector is a major factor for the economic development of a country and the economic well-being of its people as it supports people to smooth their income and increase their investment opportunities. It also impacts the social, economic and political environment of a country (Calderón \& Liu, 2003; Claessens, 2006; Erdal, Oguzhan, \& Ahmet, 2011; Houssem \& Hassene Ben, 2011; Jeanneney, Hua, \& Liang, 2006; King \& Levine, 1993). Therefore, a country needs to have sound financial systems to offer appropriate access for people to obtain money to improve their standard of living. However, there are millions of people who do not have access to financial services, especially in developing countries and therefore the demand for financial services surpasses the available supply (Barr, Kumar, \& Litan, 2007; Gobezie, 2005; Kathryn, 2005).

The microfinance industry has directed to change all that by building a financial market to meet diverse financial needs of under-served people (Armendáriz de Aghion \& Morduch, 2004; Hermes \& Lensink, 2011) and emerged merely with the objective of alleviating poverty, especially in developing countries (Brau, Hiatt, \& Woodworth, 2009; Daley-Harris, 2006). In developing countries, the formal banking sector serves only around 20 per cent of the population and the rest of them are catered to by MFIs (Berenbach \& Churchill, 1997; Robinson, 2001). Awareness of the microfinance industry has increased in recent years, bringing the number of MFIs from 618 in 1997 to 3,133 in 2005 (Daley-Harris, 2006). It is estimated that in 2007, there were around 10,000 MFIs issuing loans around the world (Ming-Yee, 2007).

Consequently, foreign capital investments (both debt and equity) in this industry has more than tripled to USD4 billion (Reille \& Forster, 2008) between 2004 and 2006. At the end of 2010, these investments had quadrupled and were calculated to be valued at USD 13 billion (Reille, Forster, \& Rozas, 2011). According to the Consultative Group to Assist the Poor (CGAP, 2004) approximately 90 per cent of one billion USD of MFI funds are mainly from taxpayers of developed countries. However, investors, creditors, donors and others stakeholders such as employees, clients and governments are now demanding transparency and accountability of funds used in the microfinance activities. In addition, the global financial crisis that started in 2007 has reduced funding availability to MFIs and donations have become more difficult to obtain and this increases the pressure to show performance and due diligence (Brown \& Gladwell, 2009; Brunnermeier, 2009; Erkens, Hung, \& Matos, 2012; Van Gool, Verbeke, Sercu, \& Baesens, 2012). Any MFI that neglects adequate control and monitoring may suffer loss of reputation and face increased challenges in terms of achieving a sustainable position in the industry (Caudill, Gropper, \& Hartarska, 2009; Hartarska \& Nadolnyak, 2007; Lapenu \& Pierret, 2006; Sinclair, 2012).

\section{Objective of the Study}

According to the Centre for the Study of Financial Innovation (CSFI, 2008) and other researchers (Hartarska, 2005; Hartarska \& Nadolnyak, 2007; Mersland \& Strøm, 2009; Rock, Otero, \& Saltzman, 1998), the nature of corporate governance practised by MFIs is less 
understood and no substantive work using multiple MFI outcomes over a number of years has been undertaken. This indicates that there is an emerging consensus to conduct more studies on corporate governance of MFIs to analyse the relationship between institutional success and corporate governance especially for developing countries. The objective of this study is to identify the relationship between governance and performance of MFIs. MFI performance comprises both financial performance and outreach. This paper pursues direction from prior studies and recommends significant corporate governance practices for MFIs that can be used as a new approach to enrich their financial performance and outreach. This paper argues that the MFIs which maintain good corporate governance practices will be financially and socially sustainable.

\section{Significance of the study}

Prior studies conducted in different industries and sectors show that good corporate governance practices leads to improved financial performance in companies (Brickley, Coles, \& Terry, 1994; Chung, Wright, \& Kedia, 2003; Dalton, Daily, Ellstrand, \& Johnson, 1998; Hossain, Cahan, \& Adams, 2000). In MFI performance literature, good governance have been emphasised as the key elements for strengthening stewardship, achieving MFIs' primary objectives and promoting further development of the industry (CSFI, 2008; Cull, Demirgüç-Kunt, \& Morduch, 2007; Gant, de Silva, Atapattu, \& Durrant, 2002; Hartarska, 2005; Labie, 2001; Mersland \& Strøm, 2009; Rock et al., 1998; van Greuning, Gallardo, \& Randhawa, 1998).

In addition, some MFI studies point out that the poor governance leads to the poor financial performance and outreach (Aboagye \& Otieku, 2010; Bassem, 2009; Hartarska, 2005; Kyereboah-Coleman, 2007; Kyereboah-Coleman \& Osei, 2008). Prior studies in the MFI area are descriptive or normative about what ought to be done. Elsewhere in the finance literature, empirical studies using micro-econometrics have analysed the economic behaviour of firms. The concerns raised in reviews of individual MFIs and normative discussions of what should constitute best practice do point to the need for better understanding of the nature of corporate governance practised by the MFIs and also, to understand the nature of the relationship that exists between institutional success and corporate governance especially for developing countries. In this paper a proposed method is described. The advantages of the approach and consequential contribution are noted.

\section{Literature Review}

In the microfinance literature, governance first appeared in 1997 and emphasised the relationships between boards of directors and the management of MFIs (Lapenu \& Pierret, 2006). Further, existing literature emphasises the importance of corporate governance for the microfinance sector as it is a significant factor for enhancing the viability of the industry (Hartarska, 2005; Labie, 2001; Mersland, 2011; Mersland \& Strøm, 2009; Varottil, 2012). Kirkpatrick and Maimbo (2002, p. 293) point out that "Five years after the notable paper by Berenbach and Churchill (1997) on microfinance regulation and supervision, the appropriate level of government-supplied regulation in the industry remains unclear. Although subsequent studies have successfully identified the basic options available to regulators, namely, no 
regulation, self-regulation, existing banking regulation, and special regulations, the literature has yet to establish a clear set of core principles which national regulators can translate into specific performance benchmarks, guidelines, rules and regulations.”

Most previous studies in this area are related to consultancy reports and general guidelines on governance. These guidelines and consultancy reports are usually applied to all industries, though some of guidelines are given for specific industries. However, general guidelines on corporate governance have not been put into practice by MFIs (Arthur, Garvey, Swan, \& Taylor, 1993; Mersland, 2009). Besides, general guidelines for corporate governance are not adequate for MFIs as there are cultural and regional differences that require the development of a specific framework for corporate governance (Gant et al., 2002). Varottil (2012) stated that MFIs need a specific corporate governance framework even when they are examined through a theoretical perspective.

As stated by Labie (2001), an agency costs' framework can be applied to the microfinance sector and he emphasises outreach performance rather than financial performance should be a priority for MFIs. This is highly important for MFIs compared with traditional firms in terms of assessing their corporate governance. However, Mersland and Strøm (2009) state that an agency cost framework cannot be applied to MFIs to deal with the relationship between financial performance and outreach. In the microfinance sector, corporate governance issues are subjected to a different set of factors that successfully target the core of the relationship between financial performance and outreach. Further, the researchers examined the relationship between firm performance and corporate governance in MFIs by using secondary data of third-party rating agencies and suggest that there is a relationship between MFI performance and governance.

Bassem (2009) uses a self-conducted survey, annual reports and mixed market data for his study on governance and performance of MFIs in Mediterranean countries and highlights that governance mechanisms can improve the performance of Euro-Mediterranean MFIs in relation to outreach and sustainability. Lapenu and Pierret (2006, p. 10) convey that the "good functioning" of the board of directors is not enough to guarantee the success of MFIs. Other governance mechanisms probably play a more important role. It is necessary to broaden the scope of a study to include all stakeholders involved (employees, managers, elected officials, clients, donors, bank partners, shareholders, the government, etc.) as well as any organisational form with a "governing" role that may have been set up at the inception of the institution . Mersland (2011) recommends in his study that stakeholders such as donors, depositors, local communities and bank associations can provide a monitoring system to boost the existence of MFIs.

However, the increasing popularity of microfinance as a development and anti-poverty tool has pushed the industry towards financial self-sufficiency and created a tension between the MFI's dual mission of financial self-sufficiency and social orientation (Sinclair, 2012). Furthermore, Varottil (2012) and Sinclair (2012) point out that the commercialisation of MFIs from non-profit institutions to for-profit institutions has created several issues in the industry. Even if the commercialisation of MFIs has assisted in scalability and outreach by broadening 
the scope of financial support for poor people, it has caused MFIs to turn back their social goals. According to Arena (2012), at present microfinance providers of are drifting away from their mission and corporate governance is being blamed, because the existing corporate governance practices available to MFIs are only influencing their ability to raise capital and that has created a perception that private interests are benefiting from the vulnerability of the poor.

It is necessary to find out to what extent corporate governance pays attention to the interests of the poorer sections of society as stakeholders (Mersland \& Strøm, 2010). Through the application of social corporate governance, MFIs can pay more attention to the poor stakeholders and mitigate the problem of getting away from the mission. As Arena (2012, p. 269) stated, "Unlike traditional corporate governance mechanisms, the social corporate governance is designed to vindicate the organisation's social and development goals. The social corporate governance mechanisms, when properly balanced against traditional corporate governance structures, alleviate the tension between financial and social development goals and provide a solution to mission drift in microfinance.” By shifting from financial aspects of governance, it is timely and important to focus on social aspects of governance to identify the appropriate corporate governance mechanisms for MFIs. The financial feasibility of MFIs can develop by having a rational approach toward financial objectives (Mersland, 2011).

\section{Corporate Governance for MFIs}

Even though many studies have been conducted to identify the relationship between corporate governance practices and firm performance, there are limited scholarly studies conducted for the microfinance industry in relation to corporate governance. The empirical analysis of good corporate governance practices in relation to MFIs is still at an immature stage and it is important to conduct more studies in this field to enhance MFIs' development (Bassem, 2009; Cull et al., 2007; Hartarska, 2005, 2009; Hartarska \& Nadolnyak, 2007; Mersland, 2009; Mersland \& Strøm, 2009). However, there is plenty of empirical evidence in the financial literature that supports the view that good corporate governance enhances the performance of a firm. The same rationale recommends that good governance practices of MFIs would enhance their performance and reduce risk. Therefore, it is important to examine the empirical evidence of corporate governance mechanisms that improves firm performance.

Previous studies done by different scholars have recognised certain aspects, such as board composition and characteristics, and their impact on firm performance (Bhagat \& Black, 1999; Daily \& Dalton, 1997; Kula, 2005; Lorsch \& MacIver, 1989; Muth \& Donaldson, 1998; Roberts, McNulty, \& Stiles, 2005). They revealed many factors to measure the corporate governance practices of a firm, such as number of directors/non-executive directors, board diversity, board size, director ownership, board compensation, CEO/chairman duality, education qualifications of board members, performance assessment of board, number of board meetings, debt and dividends (Bathula, 2008; Bhagat \& Black, 1999; Daily \& Dalton, 1997; Huse \& Solberg, 2006; Kyereboah-Coleman \& Biekpe, 2006; Lorsch \& MacIver, 1989; Roberts et al., 2005; Singh \& Vinnicombe, 2004; Solomon, 2004). A number of studies have 
also investigated the relationship between corporate governance mechanisms and organisational performance (Kiel \& Nicholson, 2003; Pearce \& Zahra, 1989; Rose, 2007; Wan \& Ong, 2005).

\subsection{Board Diversity}

In recent years, the phrase 'board diversity' has become entrenched in the corporate governance vocabulary. The Alliance for Board Diversity in 2010 found that 72.9 per cent of directorships in Fortune 100 companies were held by white men and the rest were held by minorities and women. The board diversity concept suggests that boards should reflect the structure of society and properly represent the gender, ethnicity and professional backgrounds of those within it. Boards of directors in a company need to have the right composition to provide diverse viewpoints (Milliken \& Martins, 1996). Board diversity supports on the basis of moral obligation to shareholders, stakeholders and for commercial reasons by obtaining extensive decisions (Daily \& Dalton, 2003; Kasey, Thompson, \& Wright, 1997; Mattis, 2000).

Gender diversity is considered part of the broader conception of board diversity (Milliken \& Martins, 1996) and many scholars (Huse \& Solberg, 2006; Singh \& Vinnicombe, 2004; Walt \& Ingley, 2003) have shown that few women sit on corporate boards. Even though Daily, Certo, and Dalton (2000) found similar results in USA, they also found that women's representation on boards is gradually increasing. Most women directors are not from the corporate sector but are usually outsiders or non-executive directors (Hillman, Cannella, \& Harris, 2002). When compared to men, most women directors possess staff/support managerial skills, such as legal, public relations, human resources and communications rather than operating and marketing skills.

However, gender is one of the most discussed issues, not only in the corporate governance research but also in political and societal environments. Several scholars have empirically tested the consequences of women directors on firm performance (Carter, Simkins, \& Simpson, 2003; Farrell \& Hersch, 2005; Fields \& Keys, 2003; Smith, Smith, \& Verner, 2006). According to Smith et al. (2006), women directors on boards have a significant positive impact on firm performance. Carter et al. (2003) find a positive relationship between gender diversity and firm performance. In the MFI context, Bassem (2009) notes that board diversity with a higher percentage of women enhances MFI performance.

Based on the indication given by many empirical studies, it is important to further explore the impact of gender diversity of boards on MFI performance as it leads to better corporate governance provides diverse viewpoints, values and new ideas to the boards and provokes lively boardroom discussions (Burke, 1997; Daily, Certo, \& Dalton, 1999; Huse \& Solberg, 2006; Pearce \& Zahra, 1991; Singh \& Vinnicombe, 2004). Therefore, this study argues that MFI boards are likely to have a high level of diversity.

\subsection{Board Size}

Board size is the number of members on a board. There is a belief that the number of directors can affect the performance of a company, especially its financial performance. A 
number of scholars have contended that larger boards have their benefits and when board size increases firm performance also goes up as more board members provide greater monitoring, advice and make available better linkages to the external environment (Adams \& Mehran, 2003; Coles, Daniel, \& Naveen, 2008; Hillman \& Dalziel, 2003; Klein, 1998; Pfeffer, 1972). It is easier for larger boards to monitor their managers' activities more effectively, but it would be difficult for the CEO to control the board (Pearce \& Zahra, 1989). Due to the complexity of the organisation, the CEO of the organisation needs many advocates (Klein, 1998).

In non-profit organisations, when the board has a higher number of trustees, it is easy for them to deal with operational issues and wield more control over operating activities (Oster, 1995). Also, charitable organisations can improve their efficiency with larger boards (Tinkelman, 1999). Mersland and Strøm (2009) note in their MFI study that most MFIs have a board of seven to nine directors. Bassem (2009) states that large boards with a range of expertise provide better performance for MFIs. However, Yermack (1996) points out larger boards are related with lower performance for MFIs. Furthermore, Armendariz and Labie (2011) emphasise that it is important for MFIs to select board members with an appropriate background who are able and willing to dedicate the time that effective monitoring requires.

The appropriate number of board members has been a matter of continuing debate and research gives mixed results (Dalton, Daily, Johnson, \& Ellstrand, 1999; Hermalin \& Weisbach, 2003; Jensen, 1993; Yermack, 1996). It can be seen that the number of members on a board influences firm performance as numbers affect the ability of the board to carry out its functions. Therefore, it is important to consider board size for further studies for differently structured firms such as MFIs.

\subsection{Independent Directors}

The reason for using this variable is due to the different ideas about the impact of outside directors and also to assess the composition of the board. Lorsch and MacIver (1989, p. 17) state that "there has been a growing predominance of outside directors who are there not only to provide a new perspective to top management's thinking, but also to provide the necessary oversight only possible from an outsider”. Agency theory is highly concerned about board independence and the balance between executive and non-executive directors on the board (Bathula, 2008). Lorsch and MacIver (1989) highlight that 74 per cent of directors are outsiders and among them, 69 per cent are non-management personnel with no other contacts with the organisation. Agency theorists highlight that independent boards will increase firm performance (Dalton et al., 1998; Hillman, Cannella, \& Paetzold, 2000; Lynall, Golden, \& Hillman, 2003; Van den Berghe \& Levrau, 2004). As illustrated by Dahya, Dimitrov, and McConnell (2008), there is a positive relationship between firm performance and the proportion of outside directors.

In an MFI context, Hartarska (2005) used rated and unrated MFIs in Eastern Europe to investigate the relationship between corporate governance and MFI success and his results show that more independent boards give better return on assets (ROA) whereas lower financial performance and outreach showed for the boards with employee directors. Lapenu 
and Pierret (2006) highlight the tradeoffs between outreach and financial performance of MFIs, finding tradeoffs to be influenced by stakeholders' representation on the board and providing strong support for independent boards with limited employee participation. Based on the findings stated above, this study argues that MFI boards are likely to have more independent stakeholders.

\subsection{CEO/Chairman Duality}

$\mathrm{CEO} /$ chairman influence on the board is recognised as CEO/chairman duality, which is one of the important practices in corporate governance. Duality is when the roles of CEO and chairman are carried out by the same person. Fama and Jensen (1983) note that firms that separate the two functions have improved performance. Agency theoreticians highlight the separation of the role of CEO and chairperson (Dalton et al., 1998; Jensen, 1993; Muth \& Donaldson, 1998). Jensen (1993) argues that if the function of the chair is to hire, fire, evaluate and compensate the CEO then this cannot be done when both roles are combined. Therefore, the chairperson function must not be under the control of the CEO. CEO duality restricts the independence of board and reduces the ability of boards to perform their oversight and governance roles (Millstein \& Katsh, 2003).

In the MFI context, Mersland and Strøm (2009) state that CEO/chairman duality has a positive influence on outreach of MFIs and when there is a female CEO, MFI improves its' financial performance. Further, they highlight that they cannot approve whether the MFI is better governed when the CEO and chairman are seperated. Therefore, it is important to use this characteristic to understand the power of a firm, whether both important positions belong to one person or not. If both roles are performed by one person, boards of directors will be ineffective in discharging their monitoring duties, as opportunistic behaviour by the CEO will reduce firm performance. Thus, the CEO/chairman influence on the board is used to clarify the impact on firms' performance. Similar reasoning can be applied to the microfinance industry where $\mathrm{CEO} /$ chairman duality has a positive effect on firm performance due to the effectiveness of decision making and monitoring (Allen and Gale, 2000).

\subsection{Ownership Type}

Many policy papers report that the most appropriate ownership type for MFIs is a shareholder firm that can be regulated by the banking authorities and remain independent from donors (Christen \& Rosenberg, 2000; Hardy, Holden, \& Prokopenko, 2003; Jansson, Rosales, \& Westley, 2004). Such MFIs will be able to benefit from corporate governance due to private ownership. This underlines a need to transform non-profit MFIs to for-profit ownership (Ledgerwood \& White, 2006). Prior studies have pointed out that most MFIs are now commercialising their institutions from non-profit to for-profit as shareholder firms can perform better than non-profit organisations (Hardy et al., 2003; Ivatury \& Reille, 2004; Ledgerwood \& White, 2006) and are a solution to provide low-cost credit to greater outreach (Varottil, 2012).

However, in recent MFI studies, Hartarska (2005), Mersland and Strøm (2009) and Sinclair (2012) find that the for-profit organisations' ownership structure does not advance MFIs' 
performance. Mersland and Strøm (2009) further reveal that ownership of MFIs does not matter for firm performance. However, the relationship between firm performance and ownership is ambiguous and needs to be investigated. Based on the recent findings stated above, this study emphasises the need to consider the proportion of majority ownership of the firm; whether the MFI is a non-profit organisation, for-profit organisation, member-based cooperative, or shareholder-owned firm and which of these structures is likely to demonstrate better performance.

\subsection{Corporate Mission}

The relationship between firm performance and mission statement has commonly been discussed in the strategic planning textbooks but remains unanswered (Bart \& Baetz, 1998). More focus has been given to identifying the components of the mission statement. Very few studies have focused on mission statement and firm performance research. Bart, Bontis, and Taggar (2001) point out that mission statements have a positive relationship with performance and can make a positive contribution towards performance. They also find there are intervening variables which need to be considered when assessing the relationship between mission statement and performance. Zachary, Dana, and Israel (2008) reveal that some Israeli firms with formal and written mission statements demonstrate improved performance.

In MFI related studies, some scholars are highly concerned about the clear definition of social goals which help to structure MFI activities to reach more borrowers. Arena (2012) notes MFIs have a problem with drifting away from their mission and corporate governance is being blamed. Rock et al. (1998) state that it is important for MFIs to define their mission clearly and to accurately communicate it to the institutional stakeholders, such as donors, lenders, staff and clients. Johnson, Malkamaki, and Wanjau (2006) explain how donor agencies were focusing on the results that MFIs achieve and were checking whether they were connected directly to the goals and objectives of MFIs. However, no studies have been conducted on how or the extent to which the mission of MFIs affects the performance of MFIs. It is argued that MFIs need to concentrate more on their dual mission, and therefore it is important for MFI studies to consider the relationship between the mission of MFIs and their performance.

\subsection{Internal and External Auditors}

Selecting the firm's auditor is an internal governance mechanism and links with firm performance. The internal auditor's functions offer firms an independent assurance and consulting service to evaluate and improve the effectiveness of risk management, control and governance processes (Institute of Internal Auditors [IIA], 1999). The execution of internal audit functions are highlighted in the prior literature (Antoine, 2004; Goodwin \& Kent, 2003; McCollum, 2006) and governance reports (IIA Professional Guidance, 2002; New York Stock Exchange [NYSE], 2002) as a mechanism for improving a company's internal governance. If internal auditors report directly to the board and they are independent, then there is good accountability and transparency available in the firm (Mersland \& Strøm, 2009; Sinclair, 2012). This study, therefore, will consider internal auditors as a good corporate governance 
mechanism to enhance MFI performance.

Agency theorists note a number of external controls for self-serving agents; among them are external audits (Cohen, Krishnamoorthy, \& Wright, 2002). The external auditor is considered to have an effect on the efficiency of corporate governance. Fan and Wong (2005, p. 37) stated that "Our overall results suggest that external auditors play a governance role in East Asia”. The monitoring function performed by external auditors is believed to play an essential role in ensuring the quality oversight that the companies have achieved in their financial reporting practices. Also, external auditors can provide an assurance about the quality of accounting information which is publicly reported and enable to attract outside stakeholders (Becker, Defond, Jiambalvo, \& Subramanyam, 1998; Klein, 2002; Peasnell, Pope, \& Young, 2005). Where a firm conducts external audits or reports directly to the board, and whether it issues an audited report, highly affects the performance of MFIs. Bassem (2009) and Mersland and Strøm (2009) highlight that audited financial statements improve MFI performance and need to be considered for further studies.

\subsection{Type of Donors}

The community investment movement has clearly demonstrated that investments offering minimal returns but with social value are successful for all stakeholders particularly for the microfinance industry. The affordable housing market in the USA is such a segment. It has numerous government incentives for investors, like guarantee funds and the Community Reinvestment Act (CRA) to motivate banks. Thus, the proportion of funds received from non-governmental institutions and/or foreign funds needs to be evaluated (Martyn \& Gousmett, 2011).

In non-profit organisations, large donors are acting in a similar way to blockholders in for-profit organisations by ensuring that the organisation's resources are used in an effective manner (de Andrés-Alonso, Romero-Merino, \& Cruz, 2006). Most of large donor funds have their own MFIs and actively manage all their MFIs (Sinclair, 2012). Frumkin and Kim (2001) state that large donors act like efficient monitors with their skill and power by demanding detailed plans, budgets and information for each project. It is important to consider types of donors as they represent the vertical relationship with the MFI (Mersland, 2009).

\subsection{Regulatory and Commercial Environment}

Among the external factors, the level of regulation in the microfinance sector and the commercial environment influence the manner in which MFIs deal with their performance. The current study takes into consideration the country-specific macroeconomic variables such as inflation rate, GDP growth rate, banking and financial reforms as these are considered to be the external dimension of the firm (Mersland, 2009) and they also affect the performance of MFIs (Meyer, 2002; Sinclair, 2012). Bassem (2009) states that international ratings and external governance mechanisms assist MFIs to reach their financial goals. The MFI sector needs specific, dedicated and qualified regulators who understand this sector particularly (Sinclair, 2012). Further, he states that the rating agencies should reduce due diligence expenses and provide more information about MFI investments. 
Even though a proper regulatory environment can streamline MFI activities, the available evidence indicates that it increases the cost of operation, but it is not clear whether it impacts the profitability of MFIs (Cull et al., 2007). Therefore, it is confirming that the external governance mechanism plays a limited role in MFI performance (Hartarska, 2009; Hartarska \& Nadolnyak, 2007). However, the implications arising from the regulation and commercial environment of MFIs cannot be ignored in the governance framework (Varottil, 2012). It is argued that better reforms can improve MFI performance (Christen \& Rosenberg, 2000; Hardy et al., 2003; Jansson et al., 2004; Sinclair, 2012). Based on the related studies, it is important for MFIs to have better regulatory and commercial environments to perform their activities.

\section{Conclusion}

This study identifies significant corporate governance factors that influence both the financial performance and outreach of MFIs. Good corporate governance practices relate to both the internal and external areas of MFI activities including for example fiduciary responsibility and social impact of funded activities. It is important to determine those corporate governance practices that have the greatest impact on the MFI performance and accordingly afford the potential to contribute the greatest significant impact on improving MFIs' performance in long run. Little consideration has previously been given to the mapping of outcomes with the MFI mission statement, measuring impact and evaluating processes for enhanced outreach. The audit function, both internal and external, in MFIs by providing more transparence and accountability for stakeholders, which will be of significant value to donors and investors.

This study makes an advanced contribution to the understanding of corporate governance practices in MFIs, identifying and developing an appropriate governance structure. This governance structure mechanism will enable MFIs to conduct their operations with special reference to the social performance approaching poor people who require economic development for their lives. In prior studies, the nature of corporate governance practised by MFIs are less understood and no substantive work using multiple MFI outcomes over a number of years has been undertaken. The concerns raised in reviews of individual MFIs and normative discussions of what should constitute best practice do point to the need for better understanding of the nature of corporate governance practised by the MFIs and also, to understand the nature of the relationship that exists between institutional success and corporate governance. This study points to the need for further empirical research for MFIs using micro-econometric techniques, such as regression analyses of panel data to support the conceptual literature currently available.

Insights for national policy makers regarding corporate governance practices, within specific countries, flows from the analysis undertaken. A positive impact of this study for the microfinance industry is to observe how MFIs can be strengthen to achieve better performance. The findings should encourage MFIs to consider further significant governance factors which will improve and sustain the industry. The relationship between funding and outreach is an example that informs donors' desire and decisions. The negative side is that the 
donors and investors may avoid MFIs that are not considering the good governance practices. The microfinance sector needs to be more effective if it wants to become the miracle cure for poverty. Now the sector is attempting to reinvent itself.

This study also point out guidance for selecting directors for MFI boards based on their academic and professional qualifications. The role of board members in terms of their fiduciary responsibility can be extended to improve the outreach and impact for the betterment of MFIs' overall performance by progress monitoring. For instance, appointing directors who have finance qualifications to monitor the financial activities of the MFI, a social director who ensures that the MFI adheres to its social mission and a director representing the borrowers of the MFI; what qualifications should he/she have? Further, this study concludes by highlighting the necessity of having a proper training and development in governance initiatives for MFI board to enhance the overall financial performance and social impact of the MFIs.

\section{References}

Aboagye, A. Q., \& Otieku, J. (2010). Are Ghanaian MFIs' performance associated with corporate governance? Corporate Governance, 10(3), 307-320. http://dx.doi.org/10.1108/14720701011051938

Adams, R., \& Mehran, H. (2003). Is corporate governance different for bank holding companies? Economic Policy Review - Federal Reserve Bank of New York, 9(1), 123-142. Retrieved from http://papers.ssrn.com/sol3/papers.cfm?abstract_id=795584

Allen, F., Gale, D., (2000). Comparing Financial Systems. MIT Press, Cambridge.

Antoine, R. (2004). Internal audit: Spotlight shines on its new role. Retrieved from http://accounting.smartpros.com/x45449.xml

Arena, T. (2012). Social corporate governance and the problem of mission drift in socially-oriented microfinance institutions. Columbia Journal of Law \& Social Problems, 41(3), 269-316. Retrieved from http://search.ebscohost.com/login.aspx?direct=true\&db=aph\&AN=32798348\&site=ehost-liv e

Armendariz, B., \& Labie, M. (2011). The Handbook of Microfinance. World Scientific Publishing Co. Pte. Ltd. Retrieved http://www.worldscientific.com/worldscibooks/10.1142/7645

Armendáriz de Aghion, B., \& Morduch, J. (2004). Microfinance: Where do we stand? , 135-148. Retrieved from http://www.pfsprogram.org/sites/default/files/G3_FAI_WhereWeStand_0.pdf

Arthur, N., Garvey, G., Swan, P., \& Taylor, S. (1993). Agency theory and "management research" a comment. Australian Journal of Management, 18(1), 93-102. http://dx.doi.org/10.1177/031289629301800105 
Barr, M. S., Kumar, A., \& Litan, R. E. (2007). Building Inclusive Financial Systems: A Framework for Financial Access. Washington, D.C Brookings Institution Press.

Bart, C. K., \& Baetz, M. C. (1998). The relationship between mission statements and firm performance: An exploratory study. Journal of Management Studies, 35(6), 823-853. http://dx.doi.org/10.1111/1467-6486.00121

Bart, C. K., Bontis, N., \& Taggar, S. (2001). A model of the impact of mission statements on firm performance. Management Decision, 39(1), 19-35. http://dx.doi.org/10.1108/EUM0000000005404

Bassem, B. S. (2009). Governance and performance of microfinance institutions in Mediterranean countries. Journal of Business Economics and Management, 10(1), 31-43. http://dx.doi.org/10.3846/1611-1699.2009.10.31-43

Bathula, H. (2008). Board characteristics and firm performance: evidence from New Zealand. AUT University. Retrieved from http://hdl.handle.net/10292/376

Becker, C. L., Defond, M. L., Jiambalvo, J. J., \& Subramanyam, K. R. (1998). The effect of audit quality on earnings management. Contemporary Accounting Research, 15(1), 1-24. http://dx.doi.org/10.1111/j.1911-3846.1998.tb00547.x

Berenbach, S., \& Churchill, C. (1997). Regulation and supervision of microfinance institutions Experiences from Latin America Asia and Africa. Washington, D.C.: USAID. Retrieved from http://centerforfinancialinclusionblog.files.wordpress.com/2011/10/regulation-and-supervisio n-of-microfinance-institutions.pdf

Bhagat, S., \& Black, B. (1999). The uncertain relationship between board composition and firm performance. Business Lawyer, 54(3), 921-921. Retrieved from http://www.jstor.org/stable/40687871

Brau, J. C., Hiatt, S., \& Woodworth, W. (2009). Evaluating impacts of microfinance institutions using Guatemalan data. Managerial Finance, 35(12), 953-974. http://dx.doi.org/10.1108/03074350911000025

Brickley, J. A., Coles, J. L., \& Terry, R. L. (1994). Outside directors and the adoption of poison pills. Journal of Financial Economics, 35(3), 371-390. http://dx.doi.org/10.1016/0304-405X(94)90038-8

Brown, A., \& Gladwell, S. (2009). An update on corporate governance in the wake of the credit crisis. Financial Services Quarterly. Retrieved from http://www.bellgully.co.nz/newsletters/24financial/FSQ_autumn_2009.pdf

Brunnermeier, M. K. (2009). Deciphering the liquidity and credit crunch 2007-2008. Journal of Economic Perspectives, 23(1), 77-100. http://dx.doi.org/10.1257/jep.23.1.77

Burke, R. J. (1997). Women on corporate boards of directors: A needed resource. Journal of Business Ethics, 16(9), 909-915. http://dx.doi.org/10.1023/A:1017987220508 
Calderón, C., \& Liu, L. (2003). The direction of causality between financial development and economic growth. Journal of Development Economics, 72(1), 321-334. http://dx.doi.org/10.1016/S0304-3878(03)00079-8

Carter, D. A., Simkins, B. J., \& Simpson, W. G. (2003). Corporate governance, board diversity, and firm value. Financial Review, 38(1), 33-53. http://dx.doi.org/10.1111/1540-6288.00034

Caudill, S. B., Gropper, D. M., \& Hartarska, V. (2009). Which microfinance institutions are becoming more cost effective with time? Evidence from a mixture model. Journal of Money, Credit and Banking, 41(4), 651-672. http://dx.doi.org/10.1111/j.1538-4616.2009.00226.x

CGAP. (2004). Annual Report 2004. Washington, DC: Consultative Group to Assist the Poor, The World Bank. Retrieved from http://www.cgap.org/gm/document-1.9.41932/CGAP_Annual_Report_2004.pdf

Christen, R. P., \& Rosenberg, R. (2000). The rush to regulate: Legal frameworks for microfinance. CGAP. Retrieved from http://www.cgap.org/publications/rush-regulate-legal-frameworks-microfinance

Chung, K. H., Wright, P., \& Kedia, B. (2003). Corporate governance and market valuation of capital and R\&D investments. Review of Financial Economics, 12(2), 161-172. http://dx.doi.org/10.1016/S1058-3300(02)00063-0

Claessens, S. (2006). Competitive implications of cross-border banking. World Bank Policy Research Working Paper No. 3854. Retrieved from http://papers.ssrn.com/sol3/papers.cfm?abstract_id=922980

Cohen, J., Krishnamoorthy, G., \& Wright, A. M. (2002). Corporate governance and the audit process. Contemporary Accounting Research, 19(4), 573-594. http://dx.doi.org/10.1506/983M-EPXG-4Y0R-J9YK

Coles, J. L., Daniel, N. D., \& Naveen, L. (2008). Boards: Does one size fit all? Journal of Financial Economics, 87(2), 329-356. http://dx.doi.org/10.1016/j.jfineco.2006.08.008

CSFI. (2008). Microfinance Banana Skins 2008: Risk in a booming industry. United Kingdom: Centre for the Study of Financial Innovation (CSFI). Retrieved from http://www.cgap.org/gm/document-1.9.2956/MF_BananaSkins2008.pdf

Cull, R., Demirgüç-Kunt, A., \& Morduch, J. (2007). Financial performance and outreach: A global analysis of leading microbanks. The Economic Journal, 117(517), F107-F133. http://dx.doi.org/10.1111/j.1468-0297.2007.02017.x

Dahya, J., Dimitrov, O., \& McConnell, J. J. (2008). Dominant shareholders, corporate boards, and corporate value: A cross-country analysis. Journal of Financial Economics, 87(1), 73-100. http://dx.doi.org/10.1016/j.jfineco.2006.10.005 
Daily, C. M., Certo, S. T., \& Dalton, D. R. (1999). A decade of corporate women: Some progress in the boardroom, none in the executive suite. Strategic Management Journal, 20(1), 93-99. http://dx.doi.org/10.1002/(SICI)1097-0266(199901)20:1<93::AID-SMJ18>3.0.CO;2-7

Daily, C. M., Certo, S. T., \& Dalton, D. R. (2000). The future of corporate women: Progress toward the executive suite and the boardroom. In R. J. Burke \& M. C. Mattis (Eds.), Women on corporate boards of directors: International challenges and opportunities. Netherlands: Kluwer Academic Publishers. http://dx.doi.org/10.1007/978-90-481-3401-4_2

Daily, C. M., \& Dalton, D. R. (1997). Separate, but not independent: Board leadership structure in large corporations. Corporate Governance, 5(3), 126-136. http://dx.doi.org/10.1111/1467-8683.00053

Daily, C. M., \& Dalton, D. R. (2003). Women in the boardroom: A business imperative. The Journal of Business Strategy, 24(5), 8-9. Retrieved from http://www.emeraldinsight.com/journals.htm?articleid=1491470

Daley-Harris, S. (2006). State of the microcredit summit campaign report 2006. Washington, DC: Microcredit summit campaign

Dalton, D. R., Daily, C. M., Ellstrand, A. E., \& Johnson, J. L. (1998). Meta-analytic reviews of board composition, leadership structure, and financial performance. Strategic Management Journal, 19(3),

269-290. http://dx.doi.org/10.1002/(SICI)1097-0266(199803)19:3<269::AID-SMJ950>3.3.CO;2-B

Dalton, D. R., Daily, C. M., Johnson, J. L., \& Ellstrand, A. E. (1999). Number of directors and financial performance: A meta-analysis. The Academy of Management Journal, 42(6), 674-686. http://dx.doi.org/10.2307/256988

de Andrés-Alonso, P., Romero-Merino, M. E., \& Cruz, N. M. (2006). The governance of nonprofit organizations: Empirical evidence from nongovernmental development organizations in Spain. Nonprofit and Voluntary Sector Quarterly, 35(4), 588-604. http://dx.doi.org/10.1177/0899764006289765

Erdal, D., Oguzhan, A., \& Ahmet, I. (2011). The Direction of Causality between Financial Development and Economic Growth: Evidence from Turkey. International Journal of Management, 28(1), 3-19. Retrieved from http://connection.ebscohost.com/c/articles/58663016

Erkens, D. H., Hung, M., \& Matos, P. (2012). Corporate governance in the 2007-2008 financial crisis: Evidence from financial institutions worldwide. Journal of Corporate Finance, 18(2), 389-411. http://dx.doi.org/10.1016/j.jcorpfin.2012.01.005

Fama, E. F., \& Jensen, M. C. (1983). Separation of ownership and control. Journal of Law \& Economics, 26, 301-325. http://dx.doi.org/10.1086/467037

Fan, J. P. H., \& Wong, T. J. (2005). Do external auditors perform a corporate governance role in emerging markets? Evidence from East Asia. Journal of Accounting Research, 43(1), 35-72. http://dx.doi.org/10.1111/j.1475-679x.2004.00162.x 
Farrell, K. A., \& Hersch, P. L. (2005). Additions to corporate boards: The effect of gender. Journal of Corporate Finance, 11(1), 85-106. http://dx.doi.org/10.1016/j.jcorpfin.2003.12.001

Fields, M. A., \& Keys, P. Y. (2003). The emergence of corporate governance from Wall St. to Main St.: Outside directors, board diversity, earnings management, and managerial incentives to bear risk. Financial Review, 38(1), 1-24. http://dx.doi.org/10.1111/1540-6288.00032

Frumkin, P., \& Kim, M. T. (2001). Strategic positioning and the financing of nonprofit organizations: Is efficiency rewarded in the contributions marketplace? Public Administration Review, 61(3), 266-275. http://dx.doi.org/10.1111/0033-3352.00029

Gant, R., de Silva, D., Atapattu, A., \& Durrant, S. (2002). National microfinance study of Sri Lanka: Survey of practices and policies. Australia: Australian Agency for International Development. Retrieved from http://www.microfinancegateway.org/gm/document-1.9.27354/219.pdf

Gobezie, G. (2005). Livelihoods through micro-enterprise services? Assessing supply and demand constraints for microfinance in Ethiopia (with particular reference to the Amhara Region) 3rd International Conference on the Ethiopian Economy (pp. 1-39). Addis Ababa, Ethiopia: Ethiopian Economic Association June 2-4, 2005.

Goodwin, J., \& Kent, P. (2003). Factors affecting the voluntary use of internal audit, working paper University of Queensland, St Lucia/Queensland University of Technology Brisbane, Australia.

Hardy, D. C. D. I. O., Holden, P., \& Prokopenko, V. (2003). Microfinance Institutions and Public Policy. Policy Reform

Hartarska, V. (2005). Governance and performance of microfinance institutions in Central and Eastern Europe and the newly independent states. World Development, 33(10), 1627-1643. http://dx.doi.org/10.1016/j.worlddev.2005.06.001

Hartarska, V. (2009). The impact of outside control in microfinance. Managerial Finance, 35(12), 975-989. http://dx.doi.org/10.1108/03074350911000034

Hartarska, V., \& Nadolnyak, D. (2007). Do regulated microfinance institutions achieve better sustainability and outreach? Cross-country evidence. Applied Economics, 39(10), 1207-1222. http://dx.doi.org/10.1080/00036840500461840

Hermalin, B. E., \& Weisbach, M. S. (2003). Boards of directors as an endogenously determined institution: A survey of the economic literature. Economic Policy Review Federal Reserve Bank of New York, 9(1), 7-26. Retrieved from http://ideas.repec.org/a/fip/fednep/y2003iaprp7-26nv.9no.1.html

Hermes, N., \& Lensink, R. (2011). Microfinance: Its impact, outreach, and sustainability. World Development, 39(6), 875-881. http://dx.doi.org/10.1016/j.worlddev.2009.10.021 
Hillman, A. J., Cannella, A. A., \& Harris, I. C. (2002). Women and racial minorities in the boardroom: How do directors differ? Journal of Management, 28(6), 747-763. http://dx.doi.org/10.1016/S0149-2063(02)00192-7

Hillman, A. J., Cannella, A. A., \& Paetzold, R. L. (2000). The resource dependence role of corporate directors: Strategic adaptation of board composition in response to environmental change. Journal of Management Studies, 37(2), 235-256. http://dx.doi.org/10.1111/1467-6486.00179

Hillman, A. J., \& Dalziel, T. (2003). Boards of directors and firm performance: Integrating agency and resource dependence perspectives. The Academy of Management Review, 28(3), 383-396. http://dx.doi.org/10.2307/30040728

Hossain, M., Cahan, S. F., \& Adams, M. B. (2000). The investment opportunity set and the voluntary use of outside directors: New Zealand evidence. Accounting and Business Research, 30(4), 263-273. http://dx.doi.org/10.1080/00014788.2000.9728944

Houssem, R., \& Hassene Ben, M. (2011). The Causality between financial development and economic growth: Panel data cointegration and GMM system approaches. International Journal of Economics and Finance, 3(1), 143 - 151.

Huse, M., \& Solberg, A. G. (2006). Gender-related boardroom dynamics: How Scandinavian women make and can make contributions on corporate boards. Women in Management Review, 21(2), 113-130. http://dx.doi.org/10.1108/09649420610650693

IIA Professional Guidance. (2002). Recommendation for improving corporate governance. Internal Auditor, 68

Institute of Internal Auditors [IIA]. (1999). Definition of International Auditing (The Institute of Internal Auditors, Altamonte Springs, Florida). Retrieved from http://www.iia.org.uk/en/Knowledge_Centre/global_professional_guidance/Definition.cfm

Ivatury, G., \& Reille, X. (2004). Foreign Investment in Microfinance: Debt and Equity from Quasi-Commercial Investors (Focus Notes: 25). Washington, DC: Consultative Group to Assist the Poor (CGAP), The World Bank

Jansson, T., Rosales, R., \& Westley, G. (2004). Principles and practices for regulating and supervising microfinance. Washington, DC: Inter-American Development Bank

Jeanneney, S., Hua, P., \& Liang, Z. (2006). Financial development, economic efficiency and productivity growth: Evidence from China. The Developing Economies, 44(1), 27-52. http://dx.doi.org/10.1111/j.1746-1049.2006.00002.x

Jensen, M. C. (1993). The modern industrial revolution, exit, and the failure of internal control systems. The Journal of Finance, 48(3), 831-880. http://dx.doi.org/10.1111/j.1540-6261.1993.tb04022.x

Johnson, S., Malkamaki, M., \& Wanjau, K. (2006). Tackling the 'frontiers' of microfinance in global analysis of leading microbanks. Economic Journal, 117(517), 107-133. 
Kasey, K., Thompson, S., \& Wright, M. (1997). Corporate Governance: Economic and Financial Issues. Oxford, UK: Oxford University Press.

Kathryn, I. (2005). Building inclusive financial sectors: The road to growth and poverty reduction. Journal of International Affairs, 58(2), 65-68.

Kiel, G. C., \& Nicholson, G. J. (2003). Board composition and corporate performance: How the Australian experience informs contrasting theories of corporate governance. Corporate Governance: An International Review, 11(3), 189-205. http://dx.doi.org/10.1111/1467-8683.00318

King, R. G., \& Levine, R. (1993). Finance, entrepreneurship and growth. Journal of Monetary Economics, 32(3), 513-542. http://dx.doi.org/10.1016/0304-3932(93)90028-E

Kirkpatrick, C., \& Maimbo, S. M. (2002). The implications of the evolving microfinance agenda for regulatory and supervisory policy. Development Policy Review, 20(3), 293-304. http://dx.doi.org/10.1111/1467-7679.00172

Klein, A. (1998). Firm performance and board committee structure. The Journal of Law and Economics, 41(1), 275-304. http://dx.doi.org/10.1086/467391

Klein, A. (2002). Audit committee, board of director characteristics, and earnings management. Journal of Accounting and Economics, 33(3), 375-400. http://dx.doi.org/10.1016/S0165-4101(02)00059-9

Kula, V. (2005). The Impact of the Roles, Structure and Process of Boards on Firm Performance: evidence from Turkey. Corporate Governance: An International Review, 13(2), 265-276. http://dx.doi.org/10.1111/j.1467-8683.2005.00421.x

Kyereboah-Coleman, A. (2007). The impact of capital structure on the performance of microfinance institutions. The Journal of Risk Finance, 8(1), 56-71. http://dx.doi.org/10.1108/15265940710721082

Kyereboah-Coleman, A., \& Biekpe, N. (2006). The relationship between board size board composition, CEO duality, and firm performance: experience from Ghana. Corporate Ownership and Control, 4(2), 114-122.

Kyereboah-Coleman, A., \& Osei, K. A. (2008). Outreach and profitability of microfinance institutions: the role of governance. Journal of Economic Studies, 35(3/4), 236-248. http://dx.doi.org/10.1108/01443580810887797

Labie, M. (2001). Corporate governance in microfinance organizations: A long and winding road. Management Decision, 39(4), 296-301. http://dx.doi.org/10.1108/00251740110391466

Lapenu, C., \& Pierret, D. (2006). Handbook for the Analysis of the Governance of Microfinance Institutions. IFAD. Retrieved from http://www.ifad.org/ruralfinance/pub/handbook.pdf

Ledgerwood, J., \& White, V. (2006). Transforming microfinance institutions: providing full financial services to the poor. 
Lorsch, J. W., \& MacIver, E. (1989). Pawns Or Potentates: The Reality of America's Corporate Boards. Retrieved from http://books.google.co.nz/books?id=ds0T7_5R1N8C\&printsec=frontcover\&source=gbs_ge_s ummary_r\&cad=0\#v=onepage $\& q \& \mathrm{f}=$ false

Lynall, M. D., Golden, B. R., \& Hillman, A. J. (2003). Board Composition from Adolescence to Maturity: A Multitheoretic View. The Academy of Management Review, 28(3), 416-431. http://dx.doi.org/10.5465/AMR.2003.10196743

Martyn, K., \& Gousmett, M. (2011). Where is the accountability and transparency in a charitable trading trusts? Retrieved from http://newzealandlawyer.co.nz/CurrentIssue/Issue139/139F8/tabid/2401/Default.aspx

Mattis, M. C. (2000). Women Corporate Directors in the United States. In R. J. Burke \& M. C. Mattis (Eds.), Women on corporate boards of directors: International challenges and opportunities. Netherland: Kluwer Academic Publishers. http://dx.doi.org/10.1007/978-90-481-3401-4_4

McCollum, T. (2006). On the road to good governance. The Internal Auditor, 63(5), 40-46.

Mersland, R. (2009). Corporate governance and ownership in microfinance organizations. University of Agder, Kristiansand, Norway. Retrieved from http://brage.bibsys.no/hia/bitstream/URN:NBN:no-bibsys_brage_10691/1/Mersland_Phd_20 09.pdf

Mersland, R. (2011). The governance of non-profit micro finance institutions: Lessons from history. Journal of Management \& Governance, 15(3), 327-348. http://dx.doi.org/10.1007/s10997-009-9116-7

Mersland, R., \& Strøm, R. Ø. (2009). Performance and governance in microfinance institutions. Journal of Banking and Finance, 33, 662-669. http://dx.doi.org/10.1016/j.jbankfin.2008.11.009

Mersland, R., \& Strøm, R. Ø. (2010). Microfinance Mission Drift? World Development, 38(1), 28-36. http://dx.doi.org/10.1016/j.worlddev.2009.05.006

Meyer, R. L. (2002). Track Record of Financial Institutions in Assisting the Poor in Asia (Vol. 49). Tokyo, Japan: Asian development bank institute (ADBI). Retrieved from http://ideas.repec.org/p/ess/wpaper/id2284.html

Milliken, F. J., \& Martins, L. L. (1996). Searching for common threads: Understanding the multiple effects of diversity in organizational groups. The Academy of Management Review, 21(2), 402-433. http://dx.doi.org/10.5465/AMR.1996.9605060217

Millstein, I. M., \& Katsh, S. M. (2003). The limits of corporate power: Existing constraints on the exercise of corporate discretion. Retrieved from http://books.google.co.nz/books?hl=en\&lr=\&id=WySfjuC1oagC\&oi=fnd\&pg=PR9\&dq=The +limits+of +corporate+ + power:+Existing + constraints + on+the+exercise + of + corporate + discreti on.\&ots=WROIAcB0I2\&sig=U912EOVKHG6UeNaJiX24-6QX-Iw 
Ming-Yee, H. (2007). The International Funding of Microfinance Institutions: An Overview. LuxFLAG. Retrieved

from

http://www.microfinance.lu/fileadmin/media/Publications/downloads/etudes/MF_intermediat ion_overview_01.pdf

Muth, M., \& Donaldson, L. (1998). Stewardship theory and board structure: a contingency approach. Corporate Governance, 6(1), 5-28. http://dx.doi.org/10.1111/1467-8683.00076

New York Stock Exchange [NYSE]. (2002). Corporate Accountability and Listing Standards Committee. New York: NY:

Oster, S. M. (1995). Strategic Management of Nonprofit Organizations: Theory and Cases. Retrieved from http://www.amazon.com/Strategic-Management-Nonprofit-Organizations-Theory/dp/019508 5035\#reader_0195085035

Pearce, J. A., \& Zahra, S. A. (1989). Boards of Directors and Corporate Financial Performance: A Review and Integrative Model. Journal of Management, 15(2), 291-334. http://dx.doi.org/10.1177/014920638901500208

Pearce, J. A., \& Zahra, S. A. (1991). The Relative Power of CEOs and Boards of Directors: Associations with Corporate Performance. Strategic Management Journal, 12(2), 135-153. http://dx.doi.org/10.1002/smj.4250120205

Peasnell, K. V., Pope, P. F., \& Young, S. (2005). Board Monitoring and Earnings Management: Do Outside Directors Influence Abnormal Accruals? Journal of Business $\begin{array}{llll}\text { Finance } \quad \& \quad \text { Accounting, 32(7-8), } & \text { 1311-1346. }\end{array}$ http://dx.doi.org/10.1111/j.0306-686X.2005.00630.x

Pfeffer, J. (1972). Size and composition of corporate boards of directors: The organization and its environment. Administrative Science Quarterly, 17(2), 218-228. http://dx.doi.org/10.2307/2393956

Reille, X., \& Forster, S. (2008). Foreign capital investment in microfinance: Balancing social and financial returns. Washington, D.C. USA: CGAP. Retrieved from http://www.cgap.org/gm/document-1.9.2584/FN44.pdf

Reille, X., Forster, S., \& Rozas, D. (2011). Foreign Capital Investment in Microfinance: Reassessing financial and social returns. Washington, DC: Consultative Group to Assist the Poor (CGAP). Retrieved from http://www.cgap.org/publications/foreign-capital-investment-microfinance

Roberts, J., McNulty, T., \& Stiles, P. (2005). Beyond agency conceptions of the work of the non-executive director: Creating accountability in the boardroom. British Journal of Management, 16(s1), S5-S26. http://dx.doi.org/10.1111/j.1467-8551.2005.00444.x

Robinson, M. S. (2001). The microfinance revolution:sustainable finance for the poor (pp. 1-3). Washington, DC: World Bank. http://dx.doi.org/10.1596/0-8213-4524-9 
Rock, R., Otero, M., \& Saltzman, S. (1998). Principles and practices of microfinance governance. Bethesda, United States of America: Development Alternatives, Inc. . Retrieved from

http://www.ifc.org/ifcext/corporategovernance.nsf/AttachmentsByTitle/Microfinance\%2BGo vernance\%2BPractices.pdf/\$FILE/Microfinance\%2BGovernance\%2BPractices.pdf

Rose, C. (2007). Does female board representation influence firm performance? The Danish evidence. Corporate Governance: An International Review, 15(2), 404-413. http://dx.doi.org/10.1111/j.1467-8683.2007.00570.x

Sinclair, H. (2012). Confessions of a microfinance heretic: How microlending lost its way and betrayed the poor. San Francisco, CA: Berrett-Koehler Publishers.

Singh, V., \& Vinnicombe, S. (2004). Why so few women directors in top UK boardrooms? Evidence and theoretical explanations. Corporate Governance: An International Review, 12(4), 479-488. http://dx.doi.org/10.1111/j.1467-8683.2004.00388.x

Smith, N., Smith, V., \& Verner, M. (2006). Do women in top management affect firm performance?A panel study of 2,500 Danish firms. International Journal of Productivity and Performance Management, 55(7), 569-593. http://dx.doi.org/10.1108/17410400610702160

Solomon, J. (2004). Corporate Governance and Accountability (3rd ed.). New York, NY: John Wiley \& Sons Ltd. http://dx.doi.org/10.1111/j.1467-8683.2004.00393.x

Tinkelman, D. (1999). Factors affecting the relation between donations to not-for-profit organizations and an efficiency ratio. Research in Governmental and Nonprofit Accounting, 10(1), 135-161. Retrieved from http://frr.komputerbutut.com/northeast/1999/p35.pdf

Van den Berghe, L. A. A., \& Levrau, A. (2004). Evaluating boards of directors: What constitutes a good corporate board? Corporate Governance: An International Review, 12(4), 461-478. http://dx.doi.org/10.1111/j.1467-8683.2004.00387.x

Van Gool, J., Verbeke, W., Sercu, P., \& Baesens, B. (2012). Credit scoring for microfinance: is it worth it? International Journal of Finance \& Economics, 17(2), 103-123. http://dx.doi.org/10.1002/ijfe.444

van Greuning, H., Gallardo, J., \& Randhawa, B. (1998). A framework for regulating microfinance institutions. Washington, DC: Financial Sector Development Department, The World Bank. Retrieved from http://www.microfinancegateway.org/gm/document-1.9.25003/2293_file_02293.pdf

Varottil, U. (2012). Microfinance and the corporate governance conundrum. SSRN Working Paper Series(Journal Article) 10.2139/ssrn.1986493. http://dx.doi.org/10.2139/ssrn.1986493

Walt, N. v. d., \& Ingley, C. (2003). Board dynamics and the influence of professional background, gender and ethnic diversity of directors. Corporate Governance: An International Review, 11(3), 218-234. http://dx.doi.org/10.1111/1467-8683.00320 


\section{Macrothink}

Asian Journal of Finance \& Accounting ISSN 1946-052X 2013, Vol. 5, No. 1

Wan, D., \& Ong, C. H. (2005). Board structure, process and performance: Evidence from public-listed companies in Singapore. Corporate Governance: An International Review, 13(2), 277-290. http://dx.doi.org/10.1111/j.1467-8683.2005.00422.x

Yermack, D. (1996). Higher market valuation of companies with a small board of directors. $\begin{array}{llll}\text { Journal of Financial } & \text { Economics, } & \text { 40(2), }\end{array}$ http://dx.doi.org/10.1016/0304-405X(95)00844-5

Zachary, S., Dana, L., \& Israel, D. (2008). Mission statement and performance: An evidence of "Coming of Age". Organization Development Journal, 26(2), 49-62. 